\title{
Effects of Lead on the Initial Corrosion Behavior of 316LN Stainless Steel in High-Temperature Alkaline Solution
}

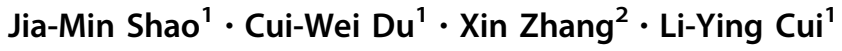 \\ Received: 18 April 2018/Revised: 4 August 2018/Published online: 29 September 2018 \\ (C) The Chinese Society for Metals and Springer-Verlag GmbH Germany, part of Springer Nature 2018
}

\begin{abstract}
The effect of lead on the initial corrosion behavior of 316LN stainless steel has been investigated by U-bend immersion experiments in $4 \mathrm{wt} \% \mathrm{NaOH}$ solutions at $300{ }^{\circ} \mathrm{C}$. Follow-up studies after soaking were carried out by scanning electron microscope, energy dispersive X-ray spectrometer, X-ray photoelectron spectrometer, Auger electron spectroscopy and Raman spectroscopy. The results show that lead affects the properties of the oxide film by changing the thickness and composition, which leads to an increase in the sensitivity of stress corrosion cracking of 316LN stainless steel. Pits and cracks appeared on the surface of $316 \mathrm{LN}$ stainless steel under both lead-free and lead-containing conditions. The corrosion products were oxides of $\mathrm{Fe}, \mathrm{Cr}$ and $\mathrm{Ni}$, and the main spinel structure on the surface of the film was $\mathrm{NiCr}_{2} \mathrm{O}_{4}$ under both conditions. However, in the presence of lead, the cracks and pits were more obvious, the thickness of the film increased from 50 to $200 \mathrm{~nm}$, and the amount of protective $\mathrm{NiCr}_{2} \mathrm{O}_{4}$ decreased. Lead was concluded to be involved in the dehydration reactions in the form of $\mathrm{Pb}(\mathrm{OH})_{2}$, which affected the normal dehydration process of the hydroxides and inhibited the formation of spinel structures. Because of the above characteristics of lead, the stability of the oxide film and its protection of $316 \mathrm{LN}$ stainless steel were reduced.
\end{abstract}

Keywords PbSCC $\cdot$ Oxide film $\cdot 316 \mathrm{LN} \cdot$ High temperature

\section{Introduction}

Austenitic stainless steels (SSs) are widely used in the nuclear power field due to their excellent corrosion resistance in high-temperature water environments [1-4]. However, stress corrosion cracking (SCC), which accelerates the failure during the service of the steels, is one of the most important problems $[3,5,6] . \mathrm{SO}_{4}{ }^{2-}, \mathrm{Cl}^{-}, \mathrm{Pb}^{2+}$ and other impurity ions can enter the loop water system through a variety of ways, resulting in an abnormal water chemical

Available online at http://link.springer.com/journal/40195

\section{Cui-Wei Du}

dcw@ustb.edu.cn

$\triangle$ Xin Zhang

zhang_xina@163.com

1 Corrosion and Protection Center, University of Science and Technology Beijing, Beijing 100083, China

2 Nuclear and Radiation Safety Center, Ministry of Environmental Protection of P. R. China, Beijing 100082, China environment, which leads to SCC failure of the nuclear power materials [2, 4, 7-14]. Lead is known to be one of the most deleterious species in reactor coolants that causes SCC of alloys. Lead-induced stress corrosion cracking (PbSCC) can occur even for a local lead concentration as low as $1 \mathrm{ppm}[15,16]$.

Studies show that lead affects the SCC sensitivity of the materials by affecting the properties of the oxide film at high-temperature lead-containing solutions. The oxide film formed on the surface of austenitic stainless steels or nickel-based alloys in high-temperature and high-pressure water environments has a double-layer structure with an inner layer of $\mathrm{Cr}$-rich oxide and an outer layer of $\mathrm{Ni}-\mathrm{Fe}-$ rich oxide [17-24]. However, the presence of lead may deteriorate the mechanical properties of the oxide film, promote the formation of $\mathrm{M}-\mathrm{OH}$ and $\mathrm{M}-(\mathrm{OH})_{2}$, and retard the dehydration of the hydroxide in the passivation film $[14,19,25,26]$. The effect of lead is strongly related to the $\mathrm{pH}$ of environment, and some experiments have shown that $\mathrm{PbSCC}$ is more likely to occur in alkaline environments $[10,14]$. 
Research on PbSCC of nuclear power materials is mainly focused on steam generator (SG) materials such as alloys 690, 600 and 800 [14-17, 25]. While, during longterm operation, lead can enter the circuit water system through various ways such as make-up water, chemical maintenance, seal welding, turbine start-up, surface dissolution on the secondary circuit side and pollution during stop of operation $[22,27,28]$. 316LN stainless steel, the main pipe material connecting the steam generator and the main coolant pump in each circuit, will inevitably be affected by impurity lead ions. So it is necessary to study the PbSCC behavior of 316LN stainless steel to assess the safety and integrity of nuclear power plants. The aim of this paper is to provide data for subsequent studies of austenitic stainless steel under high-temperature PbSCC by studying the PbSCC behavior of $316 \mathrm{LN}$ stainless steel in high-temperature alkaline solutions containing lead and lead-free.

\section{Materials and Methods}

\subsection{Materials}

The material used in this test was $316 \mathrm{LN}$ stainless steel provided by a nuclear material manufacturer. The chemical compositions are shown in Table 1 . The sample was processed into $10 \mathrm{~mm} \times 10 \mathrm{~mm} \times 2 \mathrm{~mm}$ block specimens and $50 \mathrm{~mm} \times 15 \mathrm{~mm} \times 2 \mathrm{~mm}$ U-bend specimens by wire-electrode cutting with the large surface parallel to the forging surface of the material.

\subsection{Stress Corrosion Tests}

Stress corrosion cracking tests were carried out through U-bend immersion experiments. U-bend specimens were prepared according to ASTM G30, as shown in Fig. 1. The tested surface (outer surface) was polished to 2000-grit SiC sandpaper, whereas the remaining surfaces were polished to 800 -grit paper. The specimens were then bent to $150^{\circ}$ with a U-shaped prototype and then further bent to $180^{\circ}$ by 316L stainless steel bolt. Finally, the specimens were rinsed with acetone, deionized water and alcohol, dried and stored in a vacuum dryer.

The U-bend immersion test was carried out in a $10 \mathrm{~L}$ autoclave made of Hastelloy. The compositions of the experimental solutions are shown in Table 2, and the reagents used are of analytical grade. The immersion test
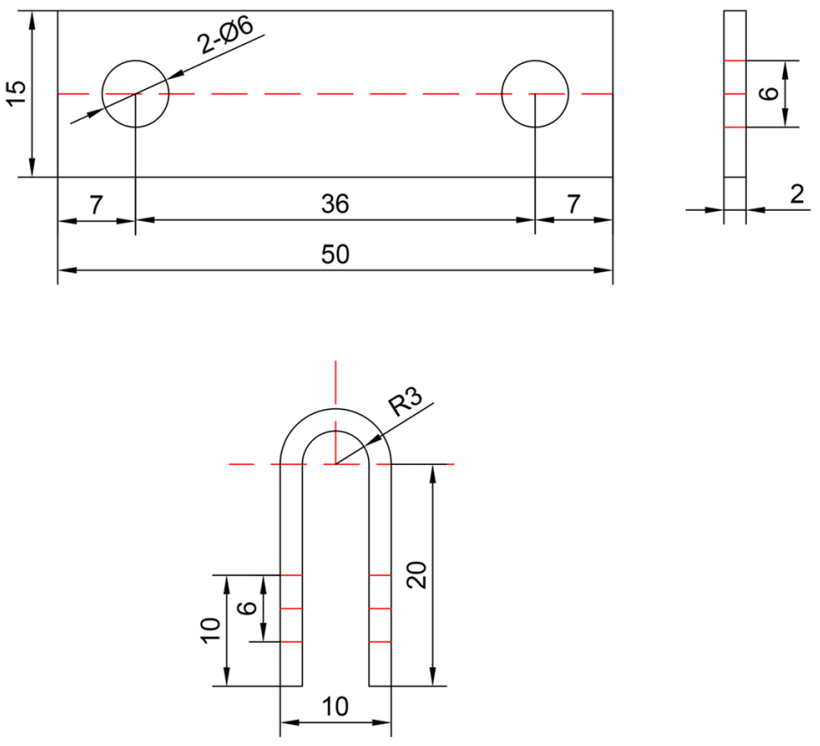

Fig. 1 Dimensions of the U-bend specimen

Table 2 The compositions of the experimental solutions

\begin{tabular}{llll}
\hline Serial number & Solution type & $\mathrm{NaOH}(\mathrm{wt} \%)$ & $\mathrm{Pb}(\mathrm{ppm})$ \\
\hline 1 & $\mathrm{NaOH}$ & 4 & - \\
2 & $\mathrm{NaOH}+\mathrm{PbO}$ & 4 & 1000 \\
\hline
\end{tabular}

was carried out at a temperature of $300{ }^{\circ} \mathrm{C}$ at $10 \mathrm{MPa}$ for a soaking time of $720 \mathrm{~h}$ and three parallel specimens were set for each condition.

In addition, the dissolved oxygen (DO) concentration was controlled below $0.2 \mathrm{ppm}$ by high-purity nitrogen to simulate the amount of DO in PWR [17, 29-31].

High-purity nitrogen was bubbled through the test solutions for $1 \mathrm{~h}$ to deoxygenate them; after the solutions were loaded into the autoclave, nitrogen was flowed through the autoclave at a high rate for $15 \mathrm{~min}$ to replace the oxygen, and then $5 \mathrm{MPa}$ of nitrogen was introduced and then released after $5 \mathrm{~min}$. This process was repeated twice, and for the third time, the initial $5 \mathrm{MPa}$ pressure of nitrogen was reduced to $1 \mathrm{MPa}$ in $5 \mathrm{~min}$, after which the charge valve was closed and the deflation valve opened until temperature rose to $104{ }^{\circ} \mathrm{C}$ to release the condensed gas. The deflation valve was then turned off, and nitrogen was added to a total pressure $10 \mathrm{MPa}$ after the temperature reached $300{ }^{\circ} \mathrm{C}$. Record of the soaking time then began.
Table 1 Chemical compositions of 316LN stainless steel (wt\%)

\begin{tabular}{lllllllllllll}
\hline Alloy & $\mathrm{C}$ & $\mathrm{Mn}$ & $\mathrm{Si}$ & $\mathrm{P}$ & $\mathrm{S}$ & $\mathrm{Cr}$ & $\mathrm{Ni}$ & $\mathrm{Mo}$ & $\mathrm{N}$ & $\mathrm{Cu}$ & $\mathrm{Co}$ & $\mathrm{Fe}$ \\
\hline 316LN SS & 0.041 & 1.41 & 0.4 & 0.011 & 0.0035 & 16.6 & 12.7 & 2.12 & 0.14 & 0.046 & $\leq 0.05$ & Balance \\
\hline
\end{tabular}




\subsection{Material Characterization}

The structure of $316 \mathrm{LN}$ was characterized by EBSD. The surface was polished to 5000-grit $\mathrm{SiC}$ sandpaper followed electropolishing until the surface was bright without any scratches. Electropolishing was then carried out in a 20 vol\% perchloric acid and $80 \mathrm{vol} \%$ acetic acid solution at a DC of $25 \mathrm{~V}$ and $1 \mathrm{~A}$ for 20-25 s at room temperature. EBSD observation was performed by an FEI QUANTA 250 SEM equipped with an electron backscatter diffraction instrument with an electron beam angle of $70^{\circ}$ and the scanning step was $4 \mu \mathrm{m}$. OIM Analysis software was used to analyze the data obtained. The surface morphology of the oxide film and the matrix after removal of the film were studied using the FEI QUANTA 250 SEM. The components of the derusting solution were $100 \mathrm{~mL} \mathrm{HCl}, 100 \mathrm{~mL}$ $\mathrm{H}_{2} \mathrm{O}$ and $1.6 \mathrm{~g}$ aminoform. The compositions of the oxide film were analyzed by energy dispersive $\mathrm{X}$-ray spectrometer (EDX), Raman spectrometer and X-ray photoelectron spectrometer. The laser wavelength of the Raman spectrometer was $532 \mathrm{~nm}$, the scanning wavelength range was $100-2000 \mathrm{~cm}^{-1}$, and the laser output power was $50 \%$. The value of $\mathrm{C} 1 \mathrm{~s}(284.8 \mathrm{eV})$ was used to correct the peak shifts of the alloying elements and oxygen in the X-ray photoelectron spectrometer (XPS) data, and curve fitting was performed with the commercial software XPSPEAK41. Auger electron spectroscopy (AES) tests were performed on a PHI-700 instrument equipped with a coaxial electron gun and a cylindrical mirror analyzer. The elemental depth profile was determined by sequential AES surface analysis and ion sputter etching using a $5.0 \mathrm{keV}$ argon ion flux, and the energy resolution was $0.1 \%$. The electron incidence angle with respect to the normal average surface plain was $30^{\circ}$. The sputtering rate, as determined on a thermally oxidized $\mathrm{SiO}_{2} / \mathrm{Si}$ standard, was about $17 \mathrm{~nm} / \mathrm{min}$.

\section{Results}

\subsection{Microstructure of 316LN Stainless Steel}

Figure 2 shows the microstructure of the material determined by electron backscattered diffraction (EBSD). The maps show that the $316 \mathrm{LN}$ stainless steel used in this work is a single-phase austenite structure with a large number of annealing twins and the average grain size is $177 \mu \mathrm{m}$.

\subsection{Observation of the Corrosion Morphology}

U-bend specimens after immersion were managed by wireelectrode cutting. The non-arcing parts were used to analyze the morphology and compositions of corrosion products and the arcing top parts were used to study the initial SCC behaviors after removing corrosion products.

Figure 3 shows scanning electron microscope (SEM) micrographs of the surface morphologies of non-arcing parts after soaking for $720 \mathrm{~h}$ in lead-containing and leadfree solutions. There are two kinds of corrosion productsparticulates and a relatively dense film. Small cracks can be observed on the film in both solutions, while they are more obvious in lead-containing solution. In order to observe the corrosion conditions of the $316 \mathrm{LN}$ stainless steel under the film, the corrosion products were removed from the samples surface.

Figure 4 is the surface micrographs of the arcing parts after removing corrosion products soaked for $720 \mathrm{~h}$ in leadcontaining and lead-free solutions. It can be seen that pits appeared on the surface of the samples under both conditions, while in lead-containing environment, the cracks are obvious and some are connected to the pits. This phenomenon indicates that $316 \mathrm{LN}$ stainless steel is highly sensitive to stress corrosion in a high-temperature alkaline environment and the pits are the primary sites to initiate SCC on steels $[32,33]$. However, the presence of lead resulted in deterioration of the passive film formed in the alkaline solution and increased the sensitivity of $316 \mathrm{LN}$ stainless steel to SCC.

\subsection{Composition of the Oxide Film}

EDX was used to analyze the major elements of the films and their rough ranges in the areas marked in Fig. 3 and the results are shown in Table 3. It can be seen that the corrosion products are oxides of iron, chromium and nickel, and the contents of $\mathrm{Ni}, \mathrm{Cr}$ and $\mathrm{Fe}$ are lower in the particulates than in the dense films. This difference is particularly pronounced in lead-containing condition. The reduction in the $\mathrm{Ni}, \mathrm{Cr}$ and $\mathrm{Fe}$ contents may change the composition of the oxide film, damage the local compactness and stability of the passive film, and increase the likelihood of pitting and stress corrosion cracking under lead-containing condition.

According to the potential-pH diagram of the $\mathrm{Ni}-\mathrm{Cr}-$ $\mathrm{Fe}-\mathrm{H}_{2} \mathrm{O}$ system at $300{ }^{\circ} \mathrm{C}$, the compositions of $\mathrm{Cr}_{2} \mathrm{O}_{3}$ and spinel oxides, which play a main role in slowing the dissolution of the passive film and reducing the corrosion rate, are stable in the corrosion products under the lead-free experimental environment [13, 22, 34]. To understand the valence and phase structure of the major elements of $316 \mathrm{LN}$ stainless steel under the two conditions, the corrosion products were analyzed by XPS and Raman spectra, respectively.

Figure 5 shows the XPS spectral of the corrosion products under the two conditions, in which $\mathrm{a}_{(1,2)}, \mathrm{b}_{(1,2)}$, $\mathrm{c}_{(1,2)}$ and $\mathrm{d}_{(1,2)}$ correspond to the peaks of $\mathrm{Cr} 2 p_{3 / 2}, \mathrm{Fe} 2 p_{3 / 2}$, 


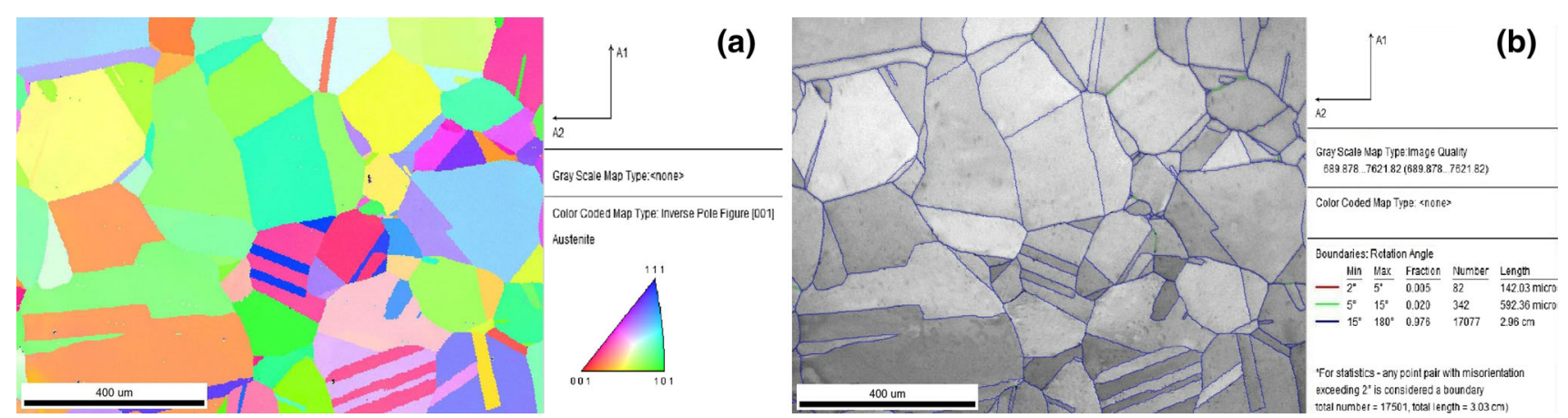

Fig. 2 EBSD results of 316LN stainless steel
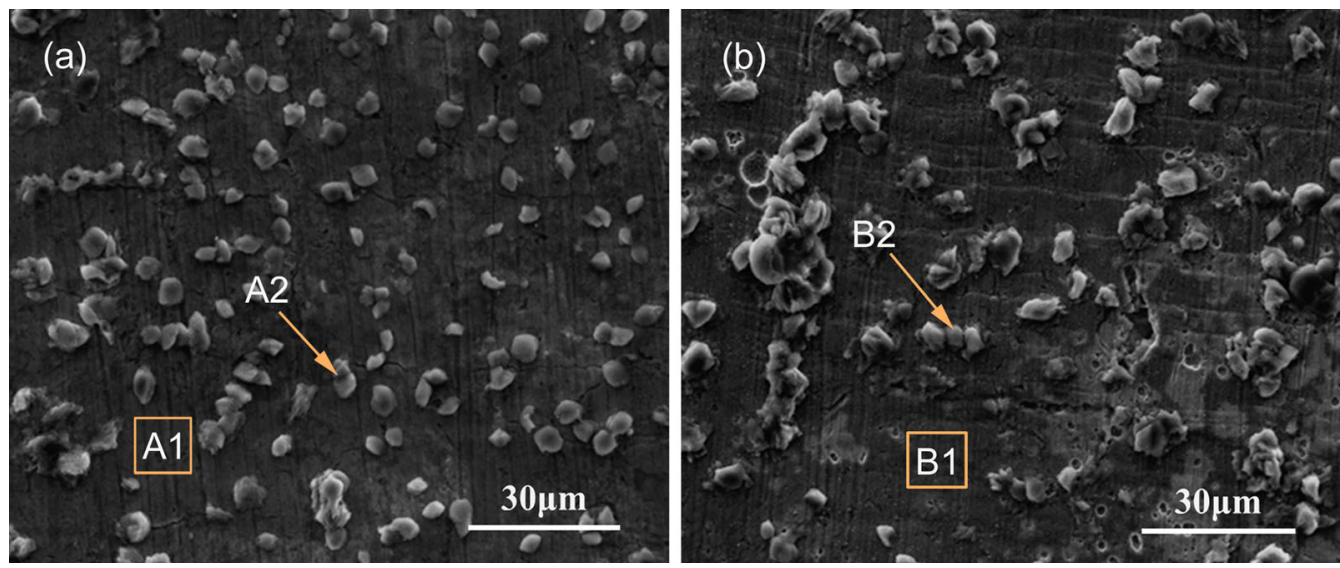

Fig. 3 SEM images of $316 \mathrm{LN}$ stainless steel specimens soaked in a $4 \% \mathrm{NaOH}$, b $4 \% \mathrm{NaOH}+\mathrm{PbO}$ for $720 \mathrm{~h}$ at $300{ }^{\circ} \mathrm{C}$
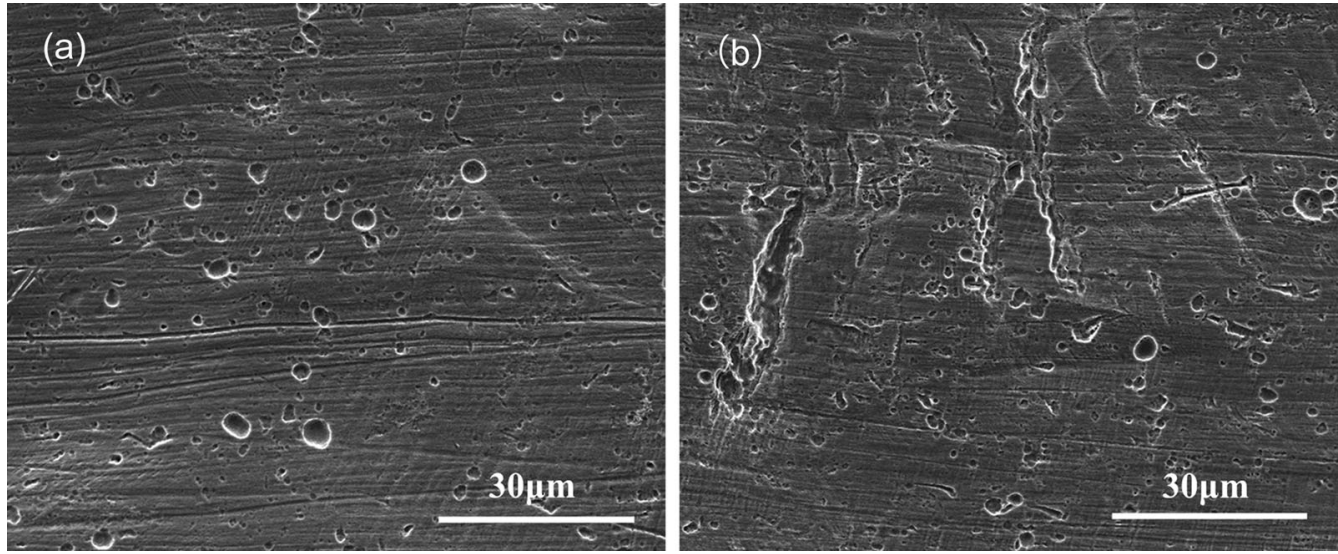

Fig. 4 SEM images after removal of the corrosion products from the $316 \mathrm{LN}$ stainless steel specimens soaked in $\mathbf{a} \mathrm{NaOH}, \mathbf{b} \mathrm{NaOH}+\mathrm{PbO}$ for $720 \mathrm{~h}$ at $300{ }^{\circ} \mathrm{C}$

$\mathrm{Ni} 2 p_{3 / 2}$ and $\mathrm{O} 1 s$, respectively [35-37]. The spectra in Fig. $5 \mathrm{a}_{1}$ show three peaks that correspond to electron binding energy of $576.4 \mathrm{eV}, 577.3 \mathrm{eV}$ and $578.4 \mathrm{eV}$, which indicate that chromium exists in a form of $\mathrm{Cr}_{2} \mathrm{O}_{3}$ or $\mathrm{NiCr}_{2} \mathrm{O}_{4}$ (a spinel structure that has similar electron binding energy to $\left.\mathrm{Cr}_{2} \mathrm{O}_{3}\right), \mathrm{Cr}(\mathrm{OH})_{3}$ and $\mathrm{CrO}_{3}$ in the lead-free condition. However, the electron binding energies of the two peaks shown in Fig. $5 \mathrm{a}_{2}$ correspond to $576.5 \mathrm{eV}$ and
$577.1 \mathrm{eV}$. It can be seen that $\mathrm{Cr}(\mathrm{OH})_{3}$ is the main form, and the contents of $\mathrm{Cr}_{2} \mathrm{O}_{3}$ or $\mathrm{NiCr}_{2} \mathrm{O}_{4}$ and $\mathrm{CrO}_{3}$ are low in the lead-containing condition. The spectra in Fig. $5 b_{1}, b_{2}$ both show one peak, which correspond to electron binding energies of $711.4 \mathrm{eV}$ and $711.0 \mathrm{eV}$, respectively. The observation of a single peak indicates that iron predominantly exists in a form of $\mathrm{Fe}_{2} \mathrm{O}_{3}$ under both conditions. Figure $5 c_{1}$ shows one peak corresponding to electron 
binding energy of $855.5 \mathrm{eV}$, which indicates that nickel exists in a form of $\mathrm{Ni}(\mathrm{OH})_{2}$ or $\mathrm{NiFe}_{2} \mathrm{O}_{4}$ in the lead-free condition. Meanwhile, no obvious peak in Fig. $5 \mathrm{c}_{2}$ reveals that the content of $\mathrm{Ni}$ is low in the lead-containing condition which is consistent with Table 3 . Figure $5 d_{1}, d_{2}$ both exhibit a single peak corresponding to electron binding energies of $531.7 \mathrm{eV}$ and $531.8 \mathrm{eV}$, respectively, indicat-

Table 3 EDX results of the regions marked in Fig. 3 (wt $\%$ )

\begin{tabular}{lllll}
\hline Elements & A1 & A2 & B1 & B2 \\
\hline $\mathrm{C}$ & 1.68 & 5.28 & 3.01 & 6.43 \\
$\mathrm{O}$ & 2.10 & 16.88 & 5.55 & 44.08 \\
$\mathrm{Cr}$ & 17.68 & 13.03 & 17.28 & 5.70 \\
$\mathrm{Fe}$ & 64.79 & 55.07 & 62.08 & 40.43 \\
$\mathrm{Ni}$ & 13.75 & 9.76 & 12.07 & - \\
$\mathrm{Pb}$ & - & - & - & 3.35 \\
\hline
\end{tabular}
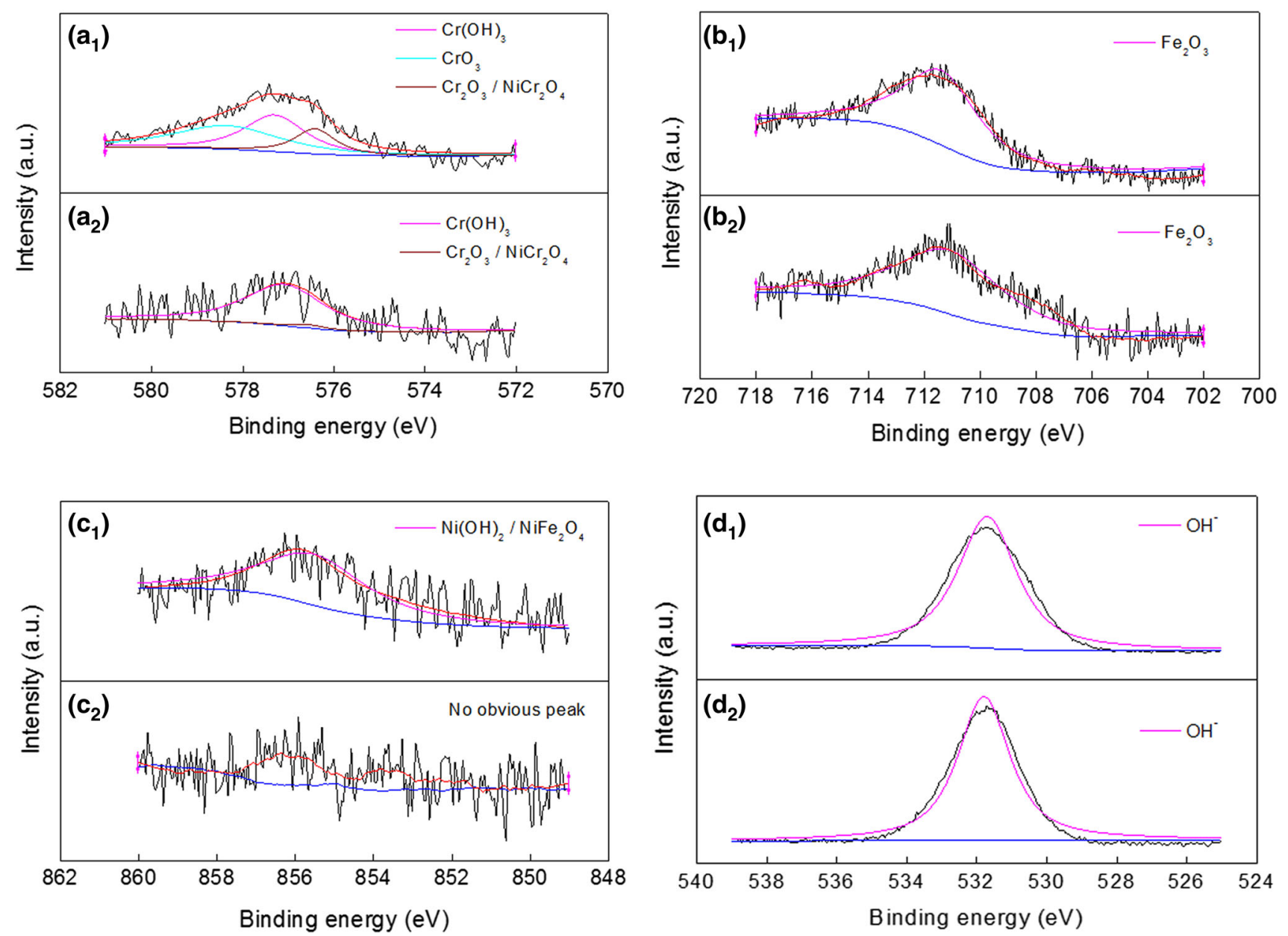

ing that the oxygen exists mainly in a form of $\mathrm{OH}^{-}$under the two conditions.

The semi-quantitative analysis of the spectra displayed in Fig. 5 was carried out by XPSPEAK41 software. The contents of $\mathrm{Cr}(\mathrm{OH})_{3}$ and $\mathrm{Cr}_{2} \mathrm{O}_{3}\left(\mathrm{NiCr}_{2} \mathrm{O}_{4}\right)$ are $43.57 \mathrm{wt} \%$ and $17.73 \mathrm{wt} \%$, respectively, in lead-free condition. In lead-containing condition, the content of $\mathrm{Cr}(\mathrm{OH})_{3}$ is $96.84 \mathrm{wt} \%$ and that of $\mathrm{Cr}_{2} \mathrm{O}_{3}$ or $\mathrm{NiCr}_{2} \mathrm{O}_{4}$, which has a protective effect on matrix, is only $3.16 \mathrm{wt} \%$.

Figure 6 shows the $\mathrm{Pb} 4 \mathrm{f}$ XPS spectra of the sample from the lead-containing solution. The two peaks with electron binding energies of $138.9 \mathrm{eV}$ and $143.9 \mathrm{eV}$ correspond to $\mathrm{Pb}(\mathrm{OH})_{2}$ (f5) and $\mathrm{Pb}(\mathrm{OH})_{2}$ (f7) or $\mathrm{PbO}$. However, in combination with the XPS spectra of $\mathrm{O} 1 s$, it can be confirmed that these two peaks correspond to $\mathrm{Pb}(\mathrm{OH})_{2}$ (f5) and $\mathrm{Pb}(\mathrm{OH})_{2}$ (f7), respectively, caused by the splitting of $\mathrm{Pb} 4 \mathrm{f}$.

This result indicates that lead is mainly present in a form of hydroxide in the film and may participate in the normal

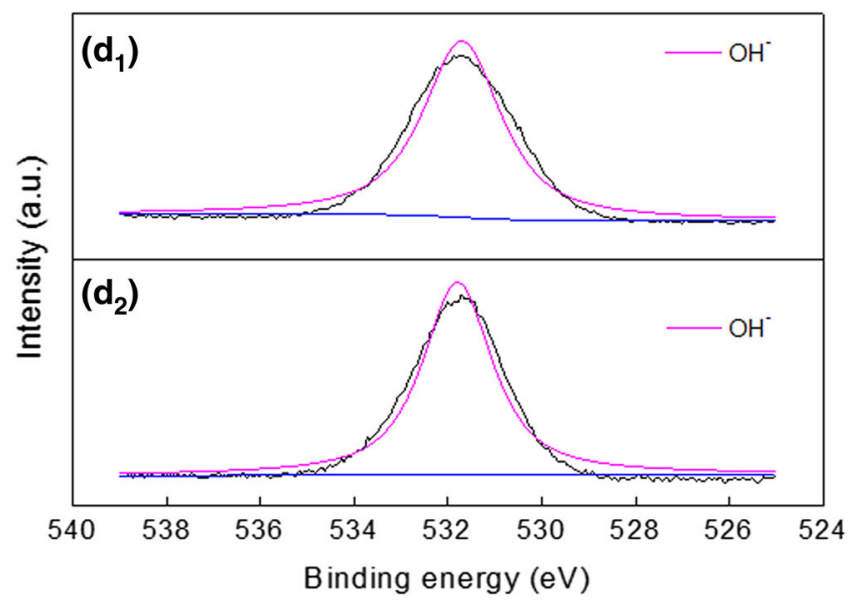

Fig. 5 XPS spectra of $\mathbf{a}_{1,2} \mathrm{Cr} 2 p_{3 / 2}, \mathbf{b}_{\mathbf{1 , 2}} \mathrm{Fe} 2 p_{3 / 2}, \mathbf{c}_{\mathbf{1 , 2}} \mathrm{Ni} 2 p_{3 / 2}, \mathbf{d}_{\mathbf{1 , 2}} \mathrm{O} 1 \mathrm{~s}$ of the oxide films on the $316 \mathrm{LN}$ stainless steel samples after soaking under different conditions for $720 \mathrm{~h}$ at $300{ }^{\circ} \mathrm{C}$. The numbers 1 and 2 correspond to $4 \% \mathrm{NaOH}$ and $4 \% \mathrm{NaOH}+\mathrm{PbO}$ solutions, respectively 


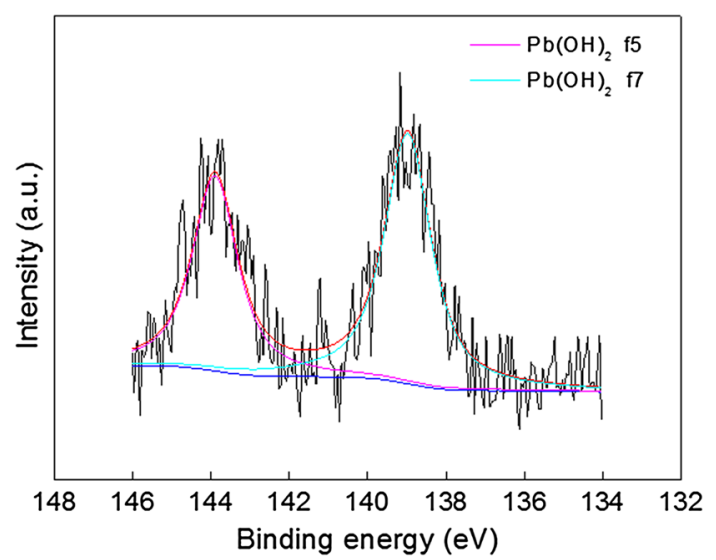

Fig. 6 XPS spectra of $\mathrm{Pb} 4 f$ in the oxide film of the $316 \mathrm{LN}$ stainless steel sample after soaking in the $4 \% \mathrm{NaOH}+\mathrm{PbO}$ solution for $720 \mathrm{~h}$ at $300{ }^{\circ} \mathrm{C}$

dehydration of the $\mathrm{Ni}$ and $\mathrm{Cr}$ hydroxides, thereby affecting the composition of the passive film [14, 15, 25].

The results of XPS displayed above and the distribution of elements provided in Table 3 show that lead can obviously affect the distribution of $\mathrm{Cr}$ and $\mathrm{Ni}$ in the corrosion products and the forms of their compounds in addition to hindering the diffusion of $\mathrm{Cr}$ and $\mathrm{Ni}$. These functions result in the transformation of the corrosion product from $\mathrm{Cr}_{2} \mathrm{O}_{3}$ or $\mathrm{NiCr}_{2} \mathrm{O}_{4}$ to $\mathrm{Cr}(\mathrm{OH})_{3}$ and $\mathrm{Ni}(\mathrm{OH})_{2}$ structures, which have poor abilities to protect the matrix.

As indicated by the results of XPS, some substances, such as $\mathrm{Cr}_{2} \mathrm{O}_{3}$ and $\mathrm{NiCr}_{2} \mathrm{O}_{4}, \mathrm{Ni}(\mathrm{OH})_{2}$ and $\mathrm{NiFe}_{2} \mathrm{O}_{4}$, cannot be distinguished due to the similarities in their electron binding energies. To further determine the composition of the film, Raman spectroscopy analysis was performed. A strong peak at $684 \mathrm{~cm}^{-1}$ can be observed on the Raman spectra in both solutions, which corresponds to the strong characteristic peak of $\mathrm{NiCr}_{2} \mathrm{O}_{4}[31,38-41]$, as shown in Fig. 7. However, in the presence of lead, the peak intensity

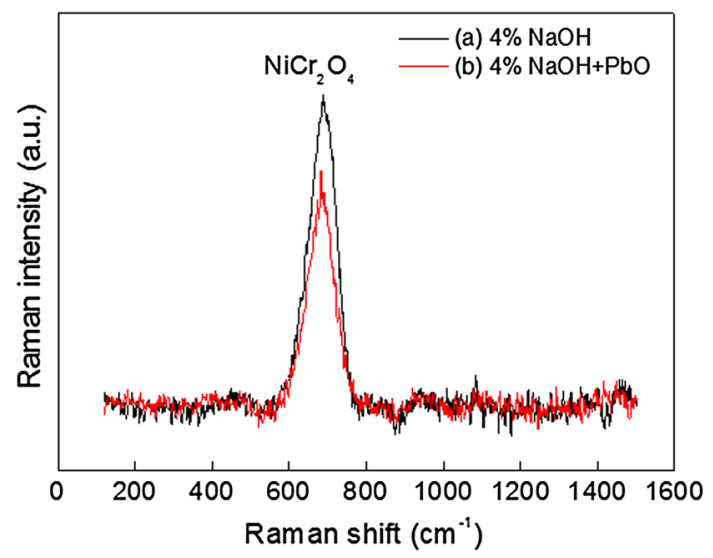

Fig. 7 Raman spectra of the oxide films on the $316 \mathrm{LN}$ stainless steel samples soaked in a $4 \% \mathrm{NaOH}$, b $4 \% \mathrm{NaOH}+\mathrm{PbO}$ solutions for $720 \mathrm{~h}$ at $300{ }^{\circ} \mathrm{C}$ of $\mathrm{NiCr}_{2} \mathrm{O}_{4}$ is obviously lower than the lead-free conditions. These results show that the main component of the spinel structure in the film of $316 \mathrm{LN}$ stainless steel is $\mathrm{NiCr}_{2} \mathrm{O}_{4}$, but the presence of lead can destroy the conversion equilibrium and inhibit the formation of the oxide and spinel structures of $\mathrm{Ni}$ and $\mathrm{Cr}$.

\subsection{Depth Distribution of Major Elements in Oxide Film}

To investigate the influence of lead on the thickness of the oxide film and the distribution of the alloying agents under the two conditions, surface and depth profile AES analyses were carried out, and the results are shown in Figs. 8 and 9. The thickness of the film is defined as the depth at which the oxygen content is reduced to half the maximum [42-44].

As illustrated in Fig. 8, the oxide film formed in the lead-containing environment contains a small amount of lead, and there is no obvious distribution of $\mathrm{Cr}$ and $\mathrm{Ni}$ on the surface, which is consistent with the results shown in Figs. 5 and 6. Compared Fig. 9a with b, there are significant differences in the thickness of the oxide film and the depth distribution of the main elements between the two conditions. According to the tendencies of $\mathrm{Ni}, \mathrm{Cr}$ and $\mathrm{Fe}$, we defined the oxide film into the inner and outer film. In outer film, the contents of $\mathrm{Fe}$ and $\mathrm{Cr}$ increased and that of $\mathrm{Ni}$ decreased slightly, while the contents of the three elements were relatively stable in inner film [4, 45-48]. Overall, the outer layer of the film is rich in $\mathrm{Fe}-\mathrm{Ni}$ and the inner layer is rich in $\mathrm{Cr}$, which are related to the diffusion rate of the elements in the oxide [18, 19]. However, the film generated in the lead-free environment is approximately $50 \mathrm{~nm}$ thick, and there is no obvious double-layer structure, while the film from the lead-containing environment is approximately $200 \mathrm{~nm}$ thick with a double-

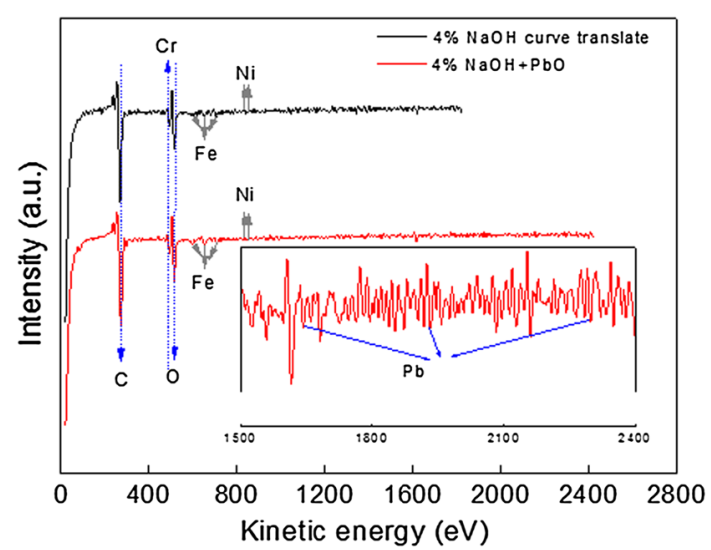

Fig. 8 AES surface analysis of the oxide films on the $316 \mathrm{LN}$ stainless steel samples soaked in a $4 \% \mathrm{NaOH}$, b $4 \% \mathrm{NaOH}+\mathrm{PbO}$ solutions for $720 \mathrm{~h}$ at $300{ }^{\circ} \mathrm{C}$ 

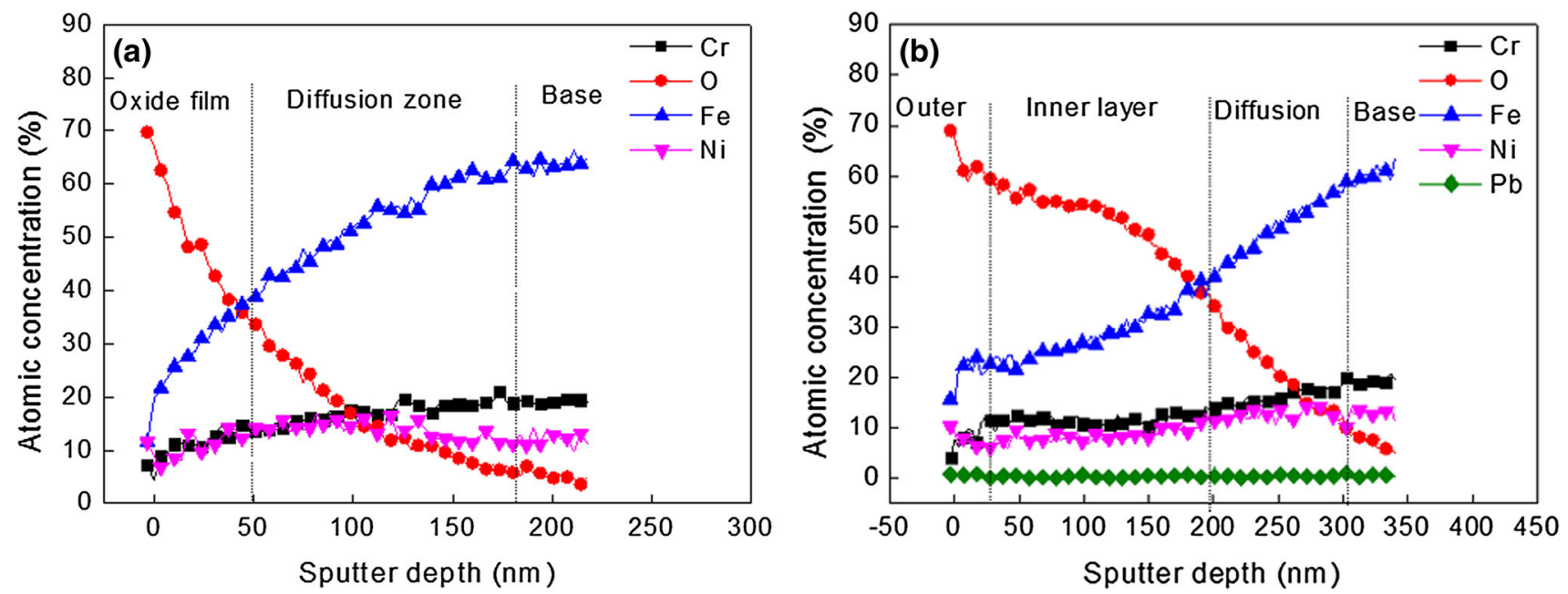

Fig. 9 AES depth profile analysis of the oxide films on the $316 \mathrm{LN}$ stainless steel samples soaked in a $4 \% \mathrm{NaOH}, \mathbf{b} 4 \% \mathrm{NaOH}+\mathrm{PbO}$ solutions for $720 \mathrm{~h}$ at $300{ }^{\circ} \mathrm{C}$

layer structure. The outer layer is similar to the surface structure formed in the lead-free condition, and the contents of $\mathrm{Fe}$ and $\mathrm{Cr}$ in the inner layer are equivalent to those in lead-free condition, which are around $20-40 \%$ and $12 \%$, respectively. However, the Ni content dropped from 12 to $8 \%$.

Moreover, as shown in Fig. 9b, the content of lead remains nearly constant at a low value with the increase of depth, which indicates that a small amount of lead can affect the composition of $\mathrm{Cr}$ and $\mathrm{Ni}$ compounds and affect the diffusion of $\mathrm{Ni}$. According to the results displayed in Figs. 5, 6 and 7, lead inhibits the formation of the spinel structures of $\mathrm{Cr}$ and $\mathrm{Ni}$, resulting in a higher content of the loosely structure $\mathrm{Cr}(\mathrm{OH})_{3}$ in the film. In summary, the adsorption of lead reduces the protective properties from the film and increases the susceptibility of local corrosion, which provide a basis for further studies on the PbSCC mechanism of austenitic stainless steel [47-50].

\section{Discussion}

The results of the EDX, XPS and AES analysis show that in high-temperature lead-containing solution, the thickness of the oxide film on 316LN stainless steel is significantly increased, and the contents of $\mathrm{Fe}, \mathrm{Cr}$ and $\mathrm{Ni}$ are reduced, and $\mathrm{Cr}$ and $\mathrm{Ni}$ exist mainly in the form of hydroxides comparing with lead-free condition. The presence of the hydroxide decreases the stability of the film, increases the corrosion sensitivity and reduces the ratio of $\mathrm{Cr}_{2} \mathrm{O}_{3}$ to spinel oxide, which have protective effects on the matrix $[13,14]$.

According to the XPS results and studies on PbSCC of nickel-based alloys, it is believed that lead is mainly involved in dehydration reactions in the form of $\mathrm{Pb}(\mathrm{OH})_{2}$, which affects the normal dehydration process (Reactions 1-4) and inhibits the formation of spinel structures (Reaction 5), resulting in a higher content of hydroxides, which are consistent with the results of Raman and XPS analyses $[14,15,25]$. There are reactions of $1-5$ as follows.

$4 \mathrm{Fe}(\mathrm{OH})_{2}+\mathrm{O}_{2} \rightarrow 2 \mathrm{Fe}_{2} \mathrm{O}_{3}+4 \mathrm{H}_{2} \mathrm{O}$,

$2 \mathrm{Fe}(\mathrm{OH})_{3} \rightarrow \mathrm{Fe}_{2} \mathrm{O}_{3}+3 \mathrm{H}_{2} \mathrm{O}$,

$2 \mathrm{Cr}(\mathrm{OH})_{3} \rightarrow \mathrm{Cr}_{2} \mathrm{O}_{3}+3 \mathrm{H}_{2} \mathrm{O}$

$\mathrm{Ni}(\mathrm{OH})_{2} \rightarrow \mathrm{NiO}+\mathrm{H}_{2} \mathrm{O}$

$(\mathrm{Ni}, \mathrm{Fe})(\mathrm{OH})_{2}+2(\mathrm{Cr}, \mathrm{Fe})(\mathrm{OH})_{3}$

$\rightarrow(\mathrm{Ni}, \mathrm{Fe})(\mathrm{Cr}, \mathrm{Fe})_{2} \mathrm{O}_{4}$ ( spinel structures $)+4 \mathrm{H}_{2} \mathrm{O}$.

Moreover, lead can affect the formation of spinel oxides and even change their structures by participating in the process of film formation [15, 44, 51, 52]. The relevant reactions are shown in (6)-(9).

$$
\begin{aligned}
& \mathrm{PbO}+\mathrm{H}_{2} \mathrm{O} \rightarrow \mathrm{Pb}(\mathrm{OH})_{2}, \\
& \quad(\mathrm{OH}) \mathrm{Ni}-\mathrm{O}-\mathrm{Pb}-\mathrm{O}-\mathrm{Cr}(\mathrm{OH})_{2}+2 \mathrm{H}_{2} \mathrm{O} \\
& \quad \rightarrow \mathrm{Pb}(\mathrm{OH})_{2} \cdot \mathrm{Ni}(\mathrm{OH})_{2} \cdot \mathrm{Cr}(\mathrm{OH})_{3}, \\
& \quad(\mathrm{OH}) \mathrm{Fe}-\mathrm{O}-\mathrm{Pb}-\mathrm{O}-\mathrm{Cr}(\mathrm{OH})_{2}+2 \mathrm{H}_{2} \mathrm{O} \\
& \rightarrow \mathrm{Pb}(\mathrm{OH})_{2} \cdot \mathrm{Fe}(\mathrm{OH})_{2} \cdot \mathrm{Cr}(\mathrm{OH})_{3}, \\
& (\mathrm{OH}) \mathrm{Ni}-\mathrm{O}-\mathrm{Pb}-\mathrm{O}-\mathrm{Fe}(\mathrm{OH})_{2}+2 \mathrm{H}_{2} \mathrm{O} \\
& \rightarrow \mathrm{Pb}(\mathrm{OH})_{2} \cdot \mathrm{Ni}(\mathrm{OH})_{2} \cdot \mathrm{Fe}(\mathrm{OH})_{3} .
\end{aligned}
$$

Due to the above characteristics, even a very low lead content evenly distributed in the oxide film (Figs. 6, 8,9) is sufficient to affect the forms of the $\mathrm{Cr}$ and $\mathrm{Ni}$ compounds and promote the formation of loose hydroxide structures of $\mathrm{Cr}$ and $\mathrm{Ni}$ (Fig. 5), thereby suppressing the formation of spinel structures of $\mathrm{Cr}$ and $\mathrm{Ni}$ (Fig. 7). These effects reduce 
the protection of the oxide film under lead-containing condition, which results in an increase in the defect density and the migration of defect pairs [31, 34, 51, 52].

According to the point defect model (PDM) of the passive film, a cation vacancy is generated at the interface between the film and solution and consumed at the interface between the metal and the film along with the generation of a variety of Schottky defects (Reactions 10,11) during the continuous formation of the passivation film, while the generation and consumption of oxygen vacancies occur in reverse. The adsorption of $\mathrm{Pb}^{2+}$ can combine with the extra cation vacancy defects at the film/solution interface through Reactions 12 and 13, which will stimulate the system to continue to generate Schottky defect pairs to maintain electrical equilibrium. In other words, the adsorption of lead promotes the formation and desorption of $\mathrm{Fe}, \mathrm{Cr}$ and $\mathrm{Ni}$ hydroxides and increases the concentration of oxygen vacancies. This increased concentration facilitates the diffusion of oxygen through the film, which in turn accelerates the corrosion of the metal/film in the regions of the defect diffusion channels (i.e., active positions), eventually enhancing the growth rate of localized corrosion (Fig. 9b) [51-54].

At the same time, owing to the enhanced formation of Schottky defect pairs, the defect pairs continuously migrate to the film/solution interface from the lattice position. This migration of defect pairs makes it easier for cations to migrate to the solution interface and form hydroxides, resulting in a larger thickness of the film under lead-containing condition, which is consistent with the AES results in this work and relevant literatures [31, 44]. Therefore, there are reactions of 10-13 as follows.

$$
\begin{aligned}
& \text { Null } \rightarrow \mathrm{V}_{\mathrm{M}}^{\prime \prime}+\mathrm{V}_{\mathrm{O}}^{.}, \\
& \mathrm{Null} \rightarrow \mathrm{V}_{\mathrm{M}}^{\prime \prime \prime}+3 \mathrm{~V}_{\mathrm{O}}^{\prime}, \\
& \mathrm{Pb}^{2+}+\mathrm{V}_{\mathrm{M}}^{\prime \prime} \rightarrow \mathrm{Pb}_{\mathrm{M}}, \mathrm{M}\left(\mathrm{Ni}, \mathrm{Fe}_{\mathrm{II}}\right), \\
& \mathrm{Pb}^{2+}+\mathrm{V}_{\mathrm{M}}^{\prime \prime \prime} \rightarrow \mathrm{Pb}_{\mathrm{M}}^{\prime}, \mathrm{M}\left(\mathrm{Cr}, \mathrm{Fe}_{\mathrm{III}}\right) .
\end{aligned}
$$

Based on the above process, the loss of metal and the process of cation diffusion on the film/metal interface are promoted under lead-containing condition compared to lead-free condition, which results in an increase in the initiation density and growth rates of pits and cracks in 316LN stainless steel under tensile stress.

\section{Conclusions}

In high-temperature alkaline solutions, lead can be adsorbed on the oxide film in the form of $\mathrm{Pb}(\mathrm{OH})_{2}$, which participates in the normal dehydration process of the hydroxides and inhibits the formation of spinel structures.
The adsorption of lead reduces the stability and protection of the oxide film which makes 316LN stainless steel more susceptible to pittings and stress corrosion cracking. This work provides a foundation for subsequent studies on the mechanism of pitting and SCC of austenitic stainless steel in high-temperature lead-containing environments.

Acknowledgements This work was supported by the National Basic Research Program of China (973 Program Project No. 2014CB643300) and the Chinese National Natural Science Foundation (Nos. U1260201 and 51471034).

\section{Compliance with Ethical Standards}

Conflict of interest The authors confirm that this article content has no conflict of interest.

\section{References}

[1] T. Terachi, T. Yamada, T. Miyamoto, K. Arioka, J. Nucl. Mater. 426, 59 (2012)

[2] J. Chen, Q. Xiao, Z. Lu, X. Ru, H. Peng, Q. Xiong, H. Li, J. Nucl. Mater. 489, 137 (2017)

[3] M. Wang, L. Chen, X. Liu, X. Ma, Corros. Sci. 81, 117 (2014)

[4] H. Ming, Z. Zhang, S. Wang, J. Wang, E. Han, W. Ke, Mater. Corros. 66, 869 (2015)

[5] F.Q. Yang, H. Xue, L.Y. Zhao, X.R. Fang, Nucl. Eng. Des. 278, 686 (2014)

[6] Y. Han, J. Mei, Q. Peng, E. Han, W. Ke, Corros. Sci. 112, 625 (2016)

[7] H. Mahdi, M. Mahdi, R. Jalali, Eng. Fail. Anal. 79, 431 (2017)

[8] D. Xia, Y. Behnamian, H. Feng, H. Fan, L. Yang, C. Shen, J. Luo, Y. Lu, S. Klimas, Corros. Sci. 87, 265 (2014)

[9] D. Du, K. Chen, H. Lu, L. Zhang, X. Shi, X. Xu, P.L. Andresen, Corros. Sci. 110, 134 (2016)

[10] D. Kim, H.P. Kim, S.S. Hwang, Nucl. Eng. Technol. 45, 67 (2013)

[11] S. Persaud, A. Carcea, J. Huang, A. Korinek, G. Botton, R. Newman, Micron 61, 62 (2014)

[12] H.P. Seifert, S. Ritter, Corros. Sci. 108, 134 (2016)

[13] J. Huang, X. Wu, E. Han, Corros. Sci. 51, 2976 (2009)

[14] B. Peng, B.T. Lu, J.L. Luo, Y.C. Lu, H.Y. Ma, J. Nucl. Mater. 378, 333 (2008)

[15] B.T. Lu, J.L. Luo, Y.C. Lu, J. Nucl. Mater. 429, 305 (2012)

[16] R.W. Staehle, J.A. Gorman, Corrosion 60, 115 (2003)

[17] N. Li, S. Shi, J. Luo, J. Lu, N. Wang, Mater. Res. Lett. 4, 1 (2016)

[18] S. Cissé, L. Laffont, B. Tanguy, M. Lafont, E. Andrieu, Corros. Sci. 56, 209 (2012)

[19] J. Huang, X. Wu, E. Han, Corros. Sci. 52, 3444 (2010)

[20] H. Sun, X. Wu, E. Han, Corros. Sci. 51, 2840 (2009)

[21] R.P. Matthews, R.D. Knusten, J.E. Westraadt, T. Couvant, Corros. Sci. 125, 175 (2017)

[22] L. Freire, M.J. Carmezim, M.G.S. Ferreira, M.F. Montemor, Electrochim. Acta 55, 6174 (2010)

[23] D. Shintani, T. Ishida, H. Izumi, T. Fukutsuka, Y. Matsuo, Y. Sugie, Corros. Sci. 50, 2840 (2008)

[24] X. Zhang, D.W. Shoesmith, Corros. Sci. 76, 424 (2013)

[25] A. Palani, B.T. Lu, L.P. Tian, J.L. Luo, Y.C. Lu, J. Nucl. Mater. 396, 189 (2010)

[26] F. Shi, P.C. Tian, N. Jia, Z.H. Ye, Y. Qi, C.M. Liu, X.W. Li, Corros. Sci. 107, 49 (2016) 
[27] B.T. Lu, J.L. Luo, Y.C. Lu, J. Electrochem. Soc. 154, C379 (2007)

[28] R.L. Zhu, L.T. Zhang, J.Q. Wang, Z.M. Zhang, E.H. Han, J. Chin. Soc. Corros. Prot. 38, 54 (2018)

[29] W. Kuang, X. Wu, E. Han, Corros. Sci. 63, 259 (2012)

[30] W. Kuang, X. Wu, E. Han, Corros. Sci. 69, 197 (2013)

[31] Q. Hou, Z.Y. Liu, C.T. Li, X.G. Li, Appl. Surf. Sci. 426, 514 (2017)

[32] Z.Y. Liu, X.G. Li, C.W. Du, Y.F. Cheng, Corros. Sci. 51, 2863 (2009)

[33] Z.Y. Liu, X.G. Li, Y.F. Cheng, Electrochim. Acta 56, 4167 (2011)

[34] B. Zhang, S. Hao, J. Wu, X. Li, C. Li, X. Di, Y. Huang, Mater. Charact. 131, 168 (2017)

[35] Z.C. Feng, X.Q. Cheng, C.F. Dong, L. Xu, X.G. Li, Corros. Sci. 52, 3646 (2010)

[36] NIST XPS Database. https://srdata.nist.gov/xps/selEnergyType. aspx. Accessed 12 Apr 2018

[37] H. Luo, C.F. Dong, K. Xiao, X.G. Li, Appl. Surf. Sci. 258, 631 (2011)

[38] L.J. Oblonsky, T.M. Devine, Corros. Sci. 37, 17 (1995)

[39] H.K. Ji, I.S. Hwang, Nucl. Eng. Des. 235, 1029 (2014)

[40] R. Sánchez-Tovar, R. Leiva-García, J. García-Antón, Thin Solid Films 576, 1 (2015)
[41] Z. Karmiol, D. Chidambaram, Metall. Mater. Trans. A Phys. Metall. Mater. Sci. 47, 2498 (2016)

[42] H. Luo, H. Su, C. Dong, K. Xiao, X. Li, Constr. Build. Mater. 96, 502 (2015)

[43] M.G. Faichuk, S. Ramamurthy, W.M. Lau, Corros. Sci. 53, 1383 (2011)

[44] M. Liu, X. Cheng, X. Li, Y. Pan, J. Li, Appl. Surf. Sci. 389, 1182 (2016)

[45] Q. Hou, Z.Y. Liu, C.T. Li, X.G. Li, Corros. Sci. 128, 154 (2017)

[46] J. Soltis, Corros. Sci. 90, 5 (2015)

[47] L. Li, X.G. Li, C.F. Dong, Y.Z. Huang, Electrochim. Acta 54, 6389 (2009)

[48] J. Xu, X. Wu, E. Han, Electrochim. Acta 71, 219 (2012)

[49] Z.Y. Liu, X.G. Li, Y.F. Cheng, Electrochem. Commun. 12, 936 (2010)

[50] Z.Y. Liu, L. Lu, Y.Z. Huang, C.W. Du, X.G. Li, Corrosion 70, 678 (2014)

[51] B. Ter-Ovanessian, B. Normand, J. Solid State Electrochem. 20, 9 (2016)

[52] B.T. Lu, J.L. Luo, Y.C. Lu, Electrochim. Acta 87, 824 (2013)

[53] H. Strehblow, Electrochim. Acta 212, 630 (2016)

[54] D. Macdonald, Electrochim. Acta 56, 1761 (2011) 